\title{
Problema apocatastazei \\ în misiunea parohială actuală
}

\section{Oana Raluca MOCEAN (PLEŞA)}

Abstract: The question of apocatastasis was debated in various theological fields, becoming more and more important in the context of the present missionary discourses. This theological view represents a power of attraction for the entire Christianity, ontologically fitting into any Christian's wish concerning the end of God's entire creation. Therefore, we consider that a revaluation of the apocatastasis - not with the meaning of a reaffirmation - in the present eschatological missionary discourse should be really necessary in the orthodox theologic field.

Keywords: eschatology, apocatastasis, missionary discourse, revaluation, hell.

Misterul vieţii de apoi a frământat adeseori minţile oamenilor, care nu s-au oprit să scruteze această taină prin interogaţii şi ipoteze. In acest context, problema apocatastazei, sub diversele ei forme, a constituit un subiect de dezbatere de mai bine de două mii de ani, de la 
filozofia antică' şi până în contemporaneitate.

În creştinism, acest termen apare pentru prima dată în Sfânta Scriptură, în predica ţinută de Sfântul Apostol Petru în pridvorul lui Solomon (Fapte 3, 19-21), iar citatul scripturistic aflat la baza apocatastazei origeniene este I Corinteni $15,23-28 \mathrm{cu}$ referire la învierea morţilor².

Conceptul de apocatastază, adică restaurarea finală a întregii creaţii, este înţeles astăzi în sens absolut ${ }^{3}$, ca mântuire a tuturor, inclusiv a păcătoşilor şi a diavolilor. Promotorul oficial al acestei teorii a fost Origen, cu toate că unele idei au fost semănate, cu puţin timp înainte, de Clement Alexandrinul, care afirma caracterul pedagogic şi vindicativ al chinurilor iadului, în defavoarea celui punitiv: „Mila şi certarea au ca scop mântuirea celor pe care îi ceartă” ${ }^{\prime \prime}$ şi „,pedeapsa

${ }^{1}$ Prima menţiune a acestui termen apare la filosoful grec presocratic, Empedocle (495-430 î.Hr.), care se referea la relaţia eternă dintre Dragoste şi Conflict în menţinerea ordinii cosmice (Cf. Edward Moore, Origen of Alexandria and apocatastasis: Some Notes on the Development of a Noble Notion, în "Quodlibet Journal", Vol. 5, Nr. 1, Ianuarie 2003). Noţiunea de restaurare a însemnat în filosofia stoică şi neopitagoreică o reaşezare a astrelor într-o anumită formă şi îmbinare şi o revenire a omenirii la vârsta de aur, urmând ca universul, cuprins în flăcări, să înceapă un nou ciclu. Ideea lumilor succesive apare şi la Origen (vezi Peri Arhon (Despre principii), III, 5,3).

${ }^{2}$ In afara acestui citat, adepţii apocatastazei aduc în sprijinul argumentaţiei lor şi alte texte scripturistice ce pot suferi diverse interpretări, precum: Luca 9,55; Ioan 12,32; Romani 11,32; I Timotei 2,4. De asemenea, unele texte liturgice apar extrem de grăitoare în acest sens: „Astăzi iadul strigă suspinând: Stricatus-a puterea mea [...]. Eu am avut morţi din veac, dar Acesta iată că pe toţi îi ridică" (Vecernia din Sfânta şi Marea zi de Sâmbătă apud Ilarion Alfeyev, Taina Credinţei. Introducere în Teologia Dogmatică Ortodoxă, Iaşi, Editura Doxologia, 2014, p. 349).

${ }^{3}$ Cf. George Remete, Suferinţa omului şi iubirea lui Dumnezeu. O introducere, ediţia a II-a revizuită şi adăugită, Alba Iulia, Editura Reîntregirea, 2006, p. 103. ${ }^{4}$ Clement Alexandrinul, Pedagogul, în „Părinţi şi Scriitori Bisericeşti (4)”, traducere, cuvânt înainte note şi indici de Pr. D. Fecioru, Bucureşti, Editura IBMBOR, 1982, I.VIII.72.1., p. 207. 
este răsplătire a răului, trimisă spre folosul celui pedepsit" ${ }^{\text {. }}$. Din această perspectivă, pentru Clement Alexandrinul eternitatea iadului depinde de libertatea creaţiei ${ }^{6}$.

Origen, care a adunat în jurul său atât admiratori, cât şi acuzatori, a susţinut, fie şi numai sub forma unor ipoteze, o reaşezare a tuturor făpturilor în starea de fericire, prin suprimarea definitivă a iadului ${ }^{7}$ : „Sfârşitul lumii şi săvârşirea tuturor vor veni când cei păcătoşi vor fi ispăşit până la capăt osânda proporţională cu fărădelegile lor. Vremea aceasta Dumnezeu singur o cunoaşte. Dar noi socotim că bunătatea lui Dumnezeu, prin mijlocirea lui Hristos, va readuce toate creaturile la un sfârşit obştesc, după ce va învinge şi supune pe toţi duşmanii"». $\mathrm{Cu}$ toate că unele texte din opera sa par a pleda pentru o apocatastază universală izvorâtă din necesitate, teologii contemporani infirmă posibilitatea susţinerii unei astfel de ipoteze datorită accentului pe care Origen îl pune, în cadrul operei sale, pe libertatea umană: „Tocmai centralitatea libertăţii este cea care exclude principial considerarea lui Origen ca un adept al teoriei apocatastazei finale a tuturor creaturilor, inclusiv a demonilor, în Dumnezeu: aceasta e posibilă numai în regimul determinist al unei filosofii a esenţei, în vreme ce pentru o filosofie şi o teologie a libertăţii ar fi o forţare inacceptabilă a voinţei libere a creaturilor raţionale"'.

${ }^{5}$ Ibidem, I.VIII.70.3, p. 206.

${ }^{6}$ David Burnfield, Patristic Universalism: An Alternative to the Traditional View of Divine Judgment, Universal-Publishers, Boca Raton, Florida, USA, 2013, pp. 193-194.

${ }^{7}$ Vezi şi Origen, Peri Arhon (Despre principii), în „Părinţi şi Scriitori Bisericeşti (8)", studiu introductiv, traducere, note de Pr. Prof. T. Bodogae, Bucureşti, Editura IBMBOR, 1982, pp.257-258; Idem, Contra lui Celsus, în „Părinţi şi Scriitori Bisericeşti (9)", studiu introductiv, traducere, note de T. Bodogae, Bucureşti, Editura IBMBOR, 1982, p. 566.

${ }^{8}$ Origen apud Sebastian Chilea, Despre ipotezele lui Origen, în „Studii Teologice", anul 1978, nr. 1-2, p. 75.

${ }^{9}$ Ioan. I. Ică jr., Prefaţă la Henri Crouzel, Origen: personajul - exegetul - omul 
$\mathrm{Cu}$ toate că unii teologi au încercat să-i atribuie Sfântului Grigorie de Nyssa doctrina apocatastazei în înţeles origenian ${ }^{10}$, constatăm că cel supranumit „Părinte al Părinţilor” a lăsat posibilitatea unei largi înţelegeri a acestui concept ${ }^{11}$.

La Sfântul Maxim Mărturisitorul nădejdea unei apocatastaze universale are la bază în principal dragostea îndelung-răbdătoare a lui Dumnezeu precum şi lipsa de subtanţialitate a răului ${ }^{12}$. Ideile acestea vor apărea mai dezvoltate la Sfântul Isaac Sirul, pentru care ,,păcatul, Gheena şi moartea nu există deloc cu Dumnezeu, căci sunt efecte, nu substanţe" ${ }^{13}$ şi , tot ceea ce bunul şi atotînţeleptul nostru Dumnezeu săvârşeşte pentru noi face spre îndreptarea noastră, că nu ne duce spre pierzanie şi spre rău, că lucrurile dureroase [ale gheenei] pe care le îngăduie vor avea un sfârşit, nu însă şi cele bune; pentru că pe cele dintâi le lasă să vină ca să primim să ne schimbăm şi să ne servească pentru bine, iar pe cele din urmă ca să rămânem pururea în ele"14.

Problema apocatastazei este una dintre tezele ce i-au atras condamnarea lui Origen ca ,părinte al tuturor ereziilor”. Sinodul al V-lea Ecumenic a condamnat teoria apocatastazei şi pe susţinătorii ei ${ }^{15}$ deoarece anulează libertatea fiinţelor umane. Pe lângă citatele

duhovnicesc - teologul, ediţia a II-a, traducere de Cristian Pop, Sibiu, Editura Deisis, 2014, pp. 13-14.

${ }^{10}$ Vezi Vasile Răducă, Antropologia Sfântului Grigorie de Nyssa. Căderea în păcat şi restaurarea omului, Bucureşti, Editura IBMBOR, 1996, p. 357.

${ }^{11}$ Cf. Ibidem, p. 373.

${ }^{12} \mathrm{Cf}$. Andrew Louth, Introducere în Teologia ortodoxă, traducere din limba engleză de Dragoş Mîrşanu, Iaşi, Editura Doxologia, 2014, p. 241.

${ }^{13}$ Isaac Sirul apud Andrew Louth, op. cit., p. 242.

${ }^{14}$ Isaac Sirul, Cuviååååååånte către singuratici despre viaţa duhului, taine dumnezeieşti, pronie şi judecată, partea a II-a recent descoperită, ediţia a II-a, studiu introductiv şi traducere de Ioan I. Ică jr, Sibiu, Editura Deisis, 2007, p. 374.

${ }^{15}$ „Cine zice sau susţine că pedeapsa demonilor şi a oamenilor nepioşi este trecătoare şi că va avea sfârşit după un timp, adecă va fi o restabilire a demonilor sau a oamenilor nepioşi, să fie anatema" (Teodor M. Popescu, Tratatul împăratului Iustinian contra lui Origen, în „Studii Teologice”, an IV (1933), 
scripturistice menţionate anterior, adepţii apocatastazei pun în discuţie diverse argumente, precum cele prin care susţin că existenţa chinurilor veşnice ar fi incompatibilă cu bunătatea lui Dumnezeu, că dreptatea lui Dumnezeu nu poate pedepsi cu veşnicia o vină şi o răutate limitate la un timp scurt, că existenţa iadului ar introduce tristeţea în rândul sfinţilor din rai la vederea celor apropiaţi şi că aceasta ar reprezenta un eşec al iubirii lui Dumnezeu ${ }^{16}$.

Conform discursului eshatologic tradiţional al Bisericii, sufletul, după moarte, nu comportă decât două posibilităţi: raiul sau iadul, acesta fiind aşezat, după Judecata particulară, ,fără a putea fí schimbat în acord cu orientarea fundamentală a năzuinţei sale [...]: o năzuinţă care a fost rafinată şi pusă la încercare pe durata vieţii pământeşti" ${ }^{17}$. Învăţătura şi Tradiţia Bisericii afirmă însă că starea celor din iad poate fi îmbunătăţită sau chiar schimbată până la Judecata finală, prin rugăciunile Bisericii. După Judecata de Apoi, însă, starea în care vor fi găsite sufletele se permanentizează.

Ceea ce apare frapant pentru omul contemporan în cadrul discursului eshatologic tradiţional este, însă, conceptul de final" atribuit Judecăţii. Ne întrebăm, împreună cu el, cum putem înţelege aplicarea acestei noţiuni iubirii nemărginite şi veşniciei lui Dumnezeu? Intrebarea care se impune este: oare Dumnezeu nu mai poate răbda sau ierta după această Judecată din urmă ori omul nu mai poate sau nu mai vrea să se pocăiască? Dacă afirmăm prima variantă, cum că ar exista totuşi posibilitatea pocăinţei după Judecata Finală, prin care o persoană din iad i-ar spune, să zicem, lui Dumnezeu: „Am greşit, iartă-mă!’, oare ne-am putea închipui dragostea lui Dumnezeu răspunzându-i: ,Ai avut timp până la Judecată, acum e prea târziu!’? Credem că acest lucru ar reprezenta un adevărat scandal pentru omul

p. 63).

${ }^{16}$ Cf. George Remete, Dogmatica Ortodoxă. Manual pentru Seminariile teologice, ediţia a patra, revăzută şi adăugită, Alba Iulia, Editura Reîntregirea, 2007, pp. 363-364.

${ }^{17}$ Andrew Louth, op. cit., p. 235. 
contemporan, din pricina incompatibilităţii acestei ipoteze cu iubirea absolută a lui Dumnezeu şi care, cel mai probabil, şi-ar manifesta un dezinteres făţiş faţă de un astfel de Dumnezeu. Aşadar, din partea lui Dumnezeu, posibilitatea iertării apare inevitabilă pentru eternitate. Pe de altă parte, dacă susţinem că există o ,încremenire totală"'18 a omului în rău şi o ,neputinţă fiinţială"19 de întoarcere şi că ,,la Judecata de Apoi, se ia notă de această orientare, acum fixată"’20, însăşi ideea de Judecată este dusă în derizoriu. Căci, dacă Dumnezeu, după moartea omului, cunoştea - conform preştiinţei Sale - că acesta va rămâne încremenit în rău şi că nu mai există pentru el vreo şansă de pocăinţă, care mai este rostul Judecăţii finale? Doar acela de ,a lua notă”, de a confirma o evidenţă?

Apare însă acum o altă întrebare: Ce consecinţe poate avea un astfel de discurs la nivelul gândirii şi trăirii omului contemporan faţă de discursul eshatologic tradiţional? Se impune o reevaluare a acestuia din urmă în contextul actual? La aceste întrebări vom încerca să răspundem în continuare.

Starea actuală a lumii creştine pare să afirme această necesitate: „Omenirea a păşit într-o etapă în care teama şi înfricoşarea fluturate ameninţător de religie, împreună cu tot alaiul lor de pedepse nemiloase, nu fac altceva decât să contribuie la succesul ateismului militant. Dacă pe vremuri ideea de iad îi ţinea pe oameni înlăuntrul Bisericii, astăzi ea îi pune pe fugă ca fiind una sadică şi îi împiedică să se întoarcă la Biserică"’21.

Dorim să subliniem de la început faptul că reevaluarea apocatastazei în discursul misionar actual nu înseamnă o afirmare la nivel doctrinar şi nici măcar la nivel de teleogumen, prin care

\footnotetext{
${ }^{18}$ George Remete, Suferinţa omului şi iubirea lui Dumnezeu. O introducere, ed. cit., p. 129.

${ }^{19}$ Ibidem .

${ }^{20}$ Andrew Louth, op. cit., p. 235.

${ }^{21}$ N. Berdiaev apud Ilarion Alfeyev, op. cit., p. 361.
} 
să susţinem necesitatea mântuirii universale absolute şi irealitatea iadului, ci reprezintă afirmarea unei posibilităţi. În sens general, ,nu putem nici nega nici susţine apocatastaza"22. Apocatastaza izvorâtă din necesitate implică cu precădere suprimarea libertăţii, fapt ce nu poate fi susţinut teologic.

$\mathrm{Cu}$ toate că opozanţii apocatastazei au avertizat asupra implicaţiilor etice şi practice ce pot decurge din susţinerea unei astfel de teorii, mai precis că aceasta ar implica cu necesitate ,devalorizarea mişcării sau a efortului personal, a importanţei timpului pentru mântuire şi deci a persoanei”’23, că „,n-ar mai exista nici o frână în calea păcatului, ba mai mult [...] ar îndemna la păcat şi 1-ar justifica"’24 şi că „,mişcarea de retragere a infernului creştin tradiţional nu este decât o păcăleală" ${ }^{25}$, deoarece ,după ce a crezut că 1-a distrus, omul s-a grăbit să-şi creeze şi să-şi descopere propriile infernuri, fără Dumnezeu şi fără diavol"26, Sfântul Isaac Sirul afirmă că teoria apocatastazei nu trebuie să îndemne la relaxare, ci să crească nădejdea, deoarece creştinul care evită păcatul doar de frica pedepsei, nu este fiu adevărat, ci slugă ${ }^{27}$. Aşadar posibilitatea mântuirii tuturor ,nu înseamnă, spre exemplu, vreo încurajare a lenei în angajarea etică, ci reprezintă cea mai severă exigenţă imaginabilă faţă de toţi: decizia în favoarea unei răbdări ce nu renunţă din principiu niciodată, ci este gata să-1 aştepte pe celălalt

${ }^{22}$ Vladimir Lossky, Teologia dogmatică, traducere de Pr. Dr. Cristian Galeriu, Bucureşti, Editura Anastasia, 2014, p. 222.

${ }^{23}$ Dumitru Stăniloae, Introducere la Sfântul Maxim Mărturisitorul, Ambigua, Bucureşti, Editura IBMBOR, 2006, p. 13.

${ }^{24}$ Sabino Chiala, Isaac Sirianul - asceză singuratică şi milă fără de sfârş̧it, traducere de Maria-Cornelia şi Ioan I. Ică jr., Sibiu, Editura Deisis, 2012, p. 358.

${ }^{25}$ Georges Minois apud Adrian Lemeni, Sensul eshatologic al creaţiei, ediţia a II-a revizuită, Bucureşti, Editura ASAB, 2007, p. 224.

${ }^{26}$ Ibidem.

${ }^{27}$ Cf. Sfântul Isaac Sirul, Cuvinte către singuratici, partea a III-a recent regăsită, ediţia a II-a, traducere de diac. Ioan I. Ică jr, Sibiu, Editura Deisis, 2007, p. 141. 
la nesfârşit” ${ }^{28}$, căci, după afirmaţia lui Toma d'Aquino ,cineva poate nădăjdui pentru un altul la viaţa veşnică, în măsura în care este una cu el în iubire" 29 . Această teorie presupune, în fond, angajarea noastră dezinteresată în procesul mântuirii, izvorâtă din dragoste faţă de Dumnezeu şi faţă de întreaga creaţie.

În mod inconştient, însă, cei mai mulţi oameni (ca să nu spunem majoritatea covârşitoare) percep iadul ca ceva străin de ei, dar pregătit pentru alţii, iar ,faptul că acolo unde omul umple iadul cu o 〈〈massa damnata 〉 de păcătoşi faţă de care el se plasează, printr-un truc oarecare, conştient sau inconştient (cu prudenţă, poate, dar totuşi încrezător) de partea cealaltă, poate fi considerat un motiv ce străbate întreaga istorie a teologiei" ${ }_{30}$.

Dacă vom continua să susţinem, în cadrul discursului misionar actual, că o bună parte a omenirii este destinată chinurilor veşnice, ne întrebăm cum ar mai putea exista ,o iubire pe deplin omenească a aproapelui, ba încă şi o iubire a duşmanilor în înţelesul lui Hristos?"’31, căci ,cine ia în considerare posibilitatea existenţei, în afară de sine însuşi, fie şi numai a unuia singur pierdut pentru veşnicie, acela cu greu poate iubi fără rezerve" ${ }_{32}$.

Sintetizând aceste idei, putem afirma că ,dacă există o interpretare eretică cu privire la mântuirea universală, poate exista şi o interpretare ortodoxă cu privire la acest subiect. Ar fi cu siguranţă o erezie să afirmăm că toţi oamenii vor fi mântuiţi în mod inevitabil, însă nu este deloc o erezie să avem nădejde şi să ne rugăm pentru mântuirea tuturor"'33. Scopul misionar al creştinismului actual este ca, prin eliberarea discursului

\footnotetext{
${ }^{28}$ Hans Urs von Balthasar, Mic discurs despre iad, traducere de Alexandru Şahighian, Bucureşti, Editura Anastasia, 1994, p. 64.

${ }^{29}$ Toma d'Aquino apud Hans Urs von Balthazar, op. cit., p. 66.

${ }^{30}$ Hans Urs von Balthazar, op. cit., p. 42.

${ }^{31}$ Ibidem, p. 47.

${ }^{32}$ Ibidem, pp. 63-64.

${ }^{33}$ Ilarion Alfeyev, op. cit., p. 360.
} 
eshatologic de „filozofemele scolastice” ${ }^{\prime 34}$ ce-1 parazitează, „,să-1 facem să se nască şi să-l salvăm în făpturi”" ${ }^{35}$ pe acest Dumnezeu iubitor şi milostiv al creştinismului. Întrucât ,pedagogia intimidării şi a terorii nu mai este eficientă, ci dimpotrivă, ea blochează intrarea în Biserică a multora dintre cei ce caută un Dumnezeu al iubirii" ${ }^{\prime 36}$, discursul eshatologic misionar actual necesită, nu o schimbare doctrinară a învătăturii, ci o mutare a accentului de pe dreptate pe iubire.

În concluzie, prin reevaluarea apocatastazei, în forma menţionată până acum, ne înscriem, de fapt, în procesul remodelării discursului misionar tradiţional, prin mutarea accentului de pe ideea de dreptate şi răsplată, rai şi iad, pe iubirea lui Dumnezeu „care vrea ca toţi să se mântuiască” (I Timotei 2,4) şi ,toţi să fie una” (Ioan 17,21) şi pe Împărăţia Lui, ce începe încă din lumea aceasta. Acest tip de discurs are în vedere „renaşterea” Dumnezeului iubitor şi iertător în sufletele oamenilor şi imprimarea dorinţei de mântuire pentru toţi oamenii, astfel încât aceasta să nu mai reprezinte cazuri izolate în creştinism (cum a fost Sfântul Siluan, Sfântul Antonie cel Mare ş.a.), ci un firesc al modului de trăire şi gândire creştină autentică. Probabil, ,cea mai teribilă armă împotriva celui rău este tocmai rugăciunea unui sfânt, iar soarta iadului depinde de voinţa transcendentă a lui Dumnezeu, dar şi de iubirea sfinţilor"’37.

Apocatastaza rămâne aşadar o problemă deschisă şi supusă dezbaterii teologiei contemporane, în aşteptarea unor noi zori ${ }^{38}$ în discursul misionar parohial actual.

\footnotetext{
${ }^{34}$ Ioan Ică, Prefaţă la Sfinţii Părinţi despre originile şi destinul cosmosului şi al omului, Sibiu, Editura Deisis, 2003, p. 13.

${ }^{35}$ Marguerite Yourcenar apud J. Deloumeau, În aşteptarea zorilor. Un creştinism pentru mâine, traducere de Giuliano Sfichi, Bucureşti, Editura Polirom, 2006, pp. $120-121$.

${ }^{36}$ Alexandre Tourintsev apud Ilarion Alfeyev, op. cit., p. 362.

${ }^{37}$ Paul Evdokimov, Iubirea nebună a lui Dumnezeu, traducere din limba franceză de Teodor Baconschi, Bucureşti, Editura Sophia, 2013, p. 112.

${ }^{38}$ Expresie folosită de Jean Deloumeau, în titlul cărţii sale: În aşteptarea zorilor.
} 
Bibliografie

1. ***, Biblia sau Sfânta Scriptură, tipărită sub îndrumarea şi cu purtarea de grijă a Preafericitului Părinte Teoctist, Patriarhul Bisericii Ortodoxe Române, cu aprobarea Sfântului Sinod, Bucureşti, Editura IBMBOR, f.a.

2. ***, Sfinţii Părinţi despre originile şi destinul cosmosului şi al omului, Sibiu, Editura Deisis, 2003.

3. Alfeyev, Ilarion, Taina Credinţei. Introducere în Teologia Dogmatică Ortodoxă, Iaşi, Editura Doxologia, 2014.

4. Balthazar, Hans Urs von, Mic discurs despre iad, traducere de Alexandru Şahighian, Bucureşti, Editura Anastasia, 1994.

5. Burnfield, David, Patristic Universalism: An Alternative to the Traditional View of Divine Judgment, Universal-Publishers, Boca Raton, Florida, USA, 2013.

6. Chiala, Sabino, Isaac Sirianul - asceză singuratică şi milă fără de sfârşit, traducere de Maria-Cornelia şi Ioan I. Ică jr., Sibiu, Editura Deisis, 2012.

7. Chilea, Sebastian, Despre ipotezele lui Origen, în „Studii Teologice", anul 1978, nr. 1-2.

8. Clement Alexandrinul, Pedagogul, în „Părinţi şi Scriitori Bisericeşti (4)", traducere, cuvânt înainte note şi indici de D. Fecioru, Bucureşti, Editura IBMBOR, 1982.

9. Crouzel, Henri, Origen: personajul - exegetul - omul duhovnicesc - teologul, ediţia a II-a, traducere de Cristian Pop, Sibiu, Editura Deisis, 2014.

10. Deloumeau, Jean, In aşteptarea zorilor. Un creştinism pentru mâine, traducere de Giuliano Sfichi, Bucureşti, Editura Polirom, 2006.

11. Evdokimov, Paul, Iubirea nebună a lui Dumnezeu, traducere din limba franceză de Teodor Baconschi, Bucureşti, Editura Sophia, 2013.

12. Isaac Sirul, Cuvinte către singuratici despre viaţa duhului, taine dumnezeieşti, pronie şi judecată, partea a II-a recent descoperită, ediţia a II-a, studiu introductiv şi traducere de Ioan I. Ică jr, Sibiu, Editura Deisis, 2007.

13. Idem, Cuvinte către singuratici, partea a III-a recent regăsită, 
ediţia a II-a, traducere de Ioan I. Ică jr, Sibiu, Editura Deisis, 2007.

14. Lossky, Vladimir, Teologia dogmatică, traducere de Cristian Galeriu, Bucureşti, Editura Anastasia, 2014.

15. Louth, Andrew, Introducere în Teologia ortodoxă, traducere din limba engleză de Dragoş Mîrşanu, Iaşi, Editura Doxologia, 2014.

16. Maxim Mărturisitorul, Ambigua, Bucureşti, Editura IBMBOR, 2006.

17. Moore, Edward, Origen of Alexandria and apocatastasis: Some Notes on the Development of a Noble Notion, în ,"Quodlibet Journal", Vol. 5, Nr. 1, Ianuarie 2003.

18. Origen, Contra lui Celsus, în „Părinţi şi Scriitori Bisericeşti (9)", studiu introductiv, traducere, note de Pr. Prof. T. Bodogae, Bucureşti, Editura IBMBOR, 1982.

19. Idem, Peri Arhon (Despre principii), în „Părinţi şi Scriitori Bisericeşti (8)", studiu introductiv, traducere, note de Pr. Prof. T. Bodogae, Editura IBMBOR, Bucureşti, 1982.

20. Popescu, Teodor M., Tratatul împăratului Iustinian contra lui Origen, în „Studii Teologice”, an IV (1933).

21. Răducă, Vasile, Antropologia Sfântului Grigorie de Nyssa. Căderea în păcat şi restaurarea omului, Bucureşti, Editura IBMBOR, 1996.

22. Remete, George, Dogmatica Ortodoxă. Manual pentru Seminariile teologice, ediţia a patra, revăzută şi adăugită, Alba Iulia, Editura Reîntregirea, 2007.

23. Idem, Suferinţa omului şi iubirea lui Dumnezeu. O introducere, ediţia a II-a revizuită şi adăugită, Alba Iulia, Editura Reîntregirea, 2006. 